\title{
Structural and Luminance Properties of Light Transmitting Concrete
}

\author{
Nadeem Gulzar Shahmir*, Mehwish Bhat \\ National Institute of Technology, Department of Civil Engineering, Srinagar 190006, India
}

Corresponding Author Email: nadeem_47phd15@nitsri.net

https://doi.org/10.18280/acsm.440305

Received: 24 February 2020

Accepted: 13 May 2020

\section{Keywords:}

energy efficient, greenhouse gas, light transmitting concrete, plastic optical fiber

\begin{abstract}
Population growth and urbanisation have resulted in exploitation of natural resources, anomalous climate change and environmental pollution. Thus, there is a need for the development of new construction techniques that will not only ensure the preservation of natural resources but at the same time will focus in making a building that is energy efficient and environment friendly. Light transmitting concrete aims to meet such requirement which helps in bringing the minimisation of artificial energy usage by directly allowing the sunlight to project through a concrete material. This paper deals with the study of mechanical and optical properties of light transmitting concrete produced by the inclusion of $2 \mathrm{~mm}$ diameter plastic optical fiber with four different densities in a concrete cube of dimension $150 \mathrm{mmx} 150 \mathrm{~mm} \times 150 \mathrm{~mm}$. The experimental results show that mechanical strength of concrete mixes containing plastic optical fiber (7x7) increases by $15.057 \%$ with light transmission intensity of 69lux greater than conventional concrete at 28 day age. Study also focused on evaluation of Rebound Hammer test results for concrete incorporated with Plastic Optical Fiber. Moreover, the stress-strain relationship showing actual behaviour of fiber concrete under compression is highlight in study. Based on the results it is concluded that the presence of plastic optical fiber in concrete material does not impair its mechanical properties and it represents a new way to harness the sun's energy because of its excellent light transmission capacity.
\end{abstract}

\section{INTRODUCTION}

Constructing a building that is energy efficient has become increasingly important in recent years. Ensuring a high quality of life while at same time reducing the energy demand of the building has always remained a key challenge. India being highly populated country, about $30 \%$ of country's total electricity consumption takes place in residential and commercial buildings [1]. This demand in energy consumption is likely to increase, as India urbanises. Rising energy consumption will lead to higher power generation affecting both capital and natural resources of the country as stated in Figure 1.

At present, India generates $80 \%$ of total electricity from fossil fuels [4]. Major contribution of electricity production comes from coal, used as a fuel in thermal power plant. Coal generates carbon dioxide which is a greenhouse gas. Thus, affecting directly our climate, health and natural environment. Therefore, the objective is to evolve a strategy to reduce energy use in buildings and greenhouse gas emission into the earth's atmosphere. One of the recent developments in construction industry is the evolution of light transmitting concrete. It's an initiative of utilising renewable source of energy in buildings. By allowing the penetration of natural daylight through the external walls of the building, light transmitting concrete has a capability to change the interior of the concrete building from dark, dull and grey to fresh, open and spacious $[5,6]$. It can bring down the meaningful amount of energy reduction in building thus increasing sustainability plus reduction in raising energy bills $[7,8]$. For the first time, a Hungarian architect Aron Losonczi introduced the idea of light transmitting concrete and successfully produced the first light transmitting concrete block in 2003, which combined his artistic inspiration and technical innovation and named his invention as LiTraCon. Started with the humble beginning, today the LTC have received a wide acceptance among the researchers. A few studies that have been carried out from time to time to address the topic of LTC. Basbash et al. [9] discussed about the effect of introducing POF on the mechanical properties of concrete specimen. The results show that for the same fiber content larger diameter have higher compressive strength. However flexural strength shows decreasing trend at all percentage of fiber content. Abdelmajeed et al. [10] discussed about the performance of concrete embedded with POF. Experimental results show that the use of POF in concrete can lead to an increase in compressive strength. Nabeel et al. [8] the paper discussed about the impact of using light transmitting concrete on energy saving in office buildings during daytime and the study concluded with the results that light transmitting concrete can substantially replace electricity. Shakir et al. [11, 12] prepared translucent composite with plastic optical fibers embedded in Self-compact mortar and the results indicated that it is possible to use SCM to produce translucent concrete containing plastic optical fiber with compressive strength between $31.3 \mathrm{MPa}$ to $40.4 \mathrm{MPa}$ at 28 days age. Thus, it can be concluded that the use of POF in concrete have significant effect on mechanical as well as illuminous property of light transmitting concrete. Basic idea behind this new innovation is to combine two opposing features of concrete big mass and transparency so as 
to evolve a material that will have a strength of concrete and translucency of glass which will not only change the traditional image of concrete but will give it a new architectural look. The materials required for the manufacturing of light transmitting concrete are same as ordinary concrete. Only the light transmitting elements (optical fiber, glass rod) are embedded in the concrete mass which have the ability of letting the light to pass through them [13]. In the present study plastic optical fiber of $2 \mathrm{~mm}$ diameter with four different densities $(5 \times 5,6 \times 6,7 \times 7,8 \times 8)$ is used as a light transmitting element. Optical fiber works on the principle of total internal reflection [14]. Because of their small size, they maintain the homogeneity of concrete and act as a reinforcement changing the behaviour of concrete from brittle to ductile. Light transmitting concrete finds its diverse range of applications in the field of construction, decoration and architectural design $[5,6,8]$ In contrast with previous study, aim of present work is to evaluate the performance of light transmitting concrete material by conducting both destructive and non-destructive methods of testing. That optimum value of fiber density satisfying both optical and mechanical resistance of light transmitting concrete is find out by comparing the results with each other. To further examine the actual behaviour of optical fiber concrete under uniaxial compression in detail, stress-strain curve is needed to investigate the various parameter. The rest of this paper is structured as follows. In Section 2, materials and methods used in carrying out the experimental work is mentioned. Section 3 , presents results and discussion of experimental work. Section 4 , gives the final conclusions.

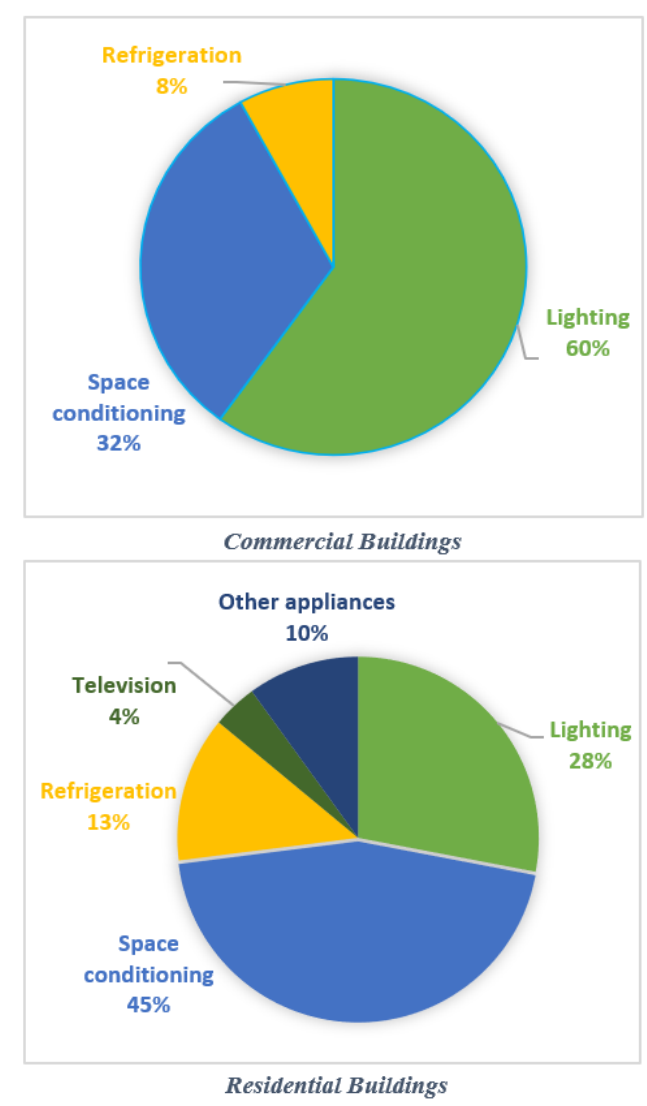

Figure 1. Electricity consumption in both commercial and residential sector in India [2, 3]

\section{MATERIALS AND METHODOLOGY}

\subsection{Materials}

The materials that were required for carrying out experimental work include cement, fine aggregate, coarse aggregate, chemical admixture, water and plastic optical fiber.

\subsubsection{Cement}

Ordinary Portland cement Khyber 43 grade manufactured in Kashmir was used. The cement was tested by following the guidelines of Indian standard code. The various properties of cement are listed in Table 1

Table 1. Properties of cement (Khyber 43 grade)

\begin{tabular}{|c|c|c|c|}
\hline Properties & $\begin{array}{l}\text { Test } \\
\text { results }\end{array}$ & $\begin{array}{c}\text { Indian standard } \\
\text { code }\end{array}$ & IS Code limits \\
\hline $\begin{array}{c}\text { Normal } \\
\text { consistency } \\
\text { (Vicat } \\
\text { apparatus) }\end{array}$ & $30 \%$ & $\begin{array}{c}\text { IS: } 4031 \text { (Part 4)- } \\
1988\end{array}$ & \\
\hline $\begin{array}{l}\text { Initial and } \\
\text { setting time } \\
\text { (Vicat } \\
\text { apparatus) }\end{array}$ & $30 \mathrm{~min}$ & $\begin{array}{c}\text { IS: } 4031 \text { (Part 5)- } \\
1988\end{array}$ & $\begin{array}{l}\text { Not less than } 30 \\
\text { minutes for } \\
\text { ordinary cement }\end{array}$ \\
\hline $\begin{array}{l}\text { Final setting } \\
\text { time (Vicat } \\
\text { apparatus) }\end{array}$ & $510 \mathrm{~min}$ & $\begin{array}{c}\text { IS: } 4031 \text { (Part 5)- } \\
1988\end{array}$ & $\begin{array}{l}\text { Not more than } \\
600 \text { minutes }\end{array}$ \\
\hline $\begin{array}{l}\text { Specific } \\
\text { gravity }\end{array}$ & 3.125 & IS: 2720 (Part 3) & \\
\hline $\begin{array}{c}\text { Soundness (Le- } \\
\text { Chatelier's } \\
\text { Expansion) }\end{array}$ & $\begin{array}{c}\text { Average } \\
\text { value } \\
2 \mathrm{~mm}\end{array}$ & & $\begin{array}{l}\text { Should not be } \\
\text { more than } 10 \mathrm{~mm} \\
\text { for ordinary } \\
\text { cement }\end{array}$ \\
\hline $\begin{array}{c}\text { Fineness (Sieve } \\
\text { test) }\end{array}$ & $6.67 \%$ & $\begin{array}{c}\text { IS: } 4031 \text { (Part 1)- } \\
1996\end{array}$ & $\begin{array}{l}\text { Weight shall not } \\
\text { exceed } 10 \% \text { for } \\
\text { ordinary cement }\end{array}$ \\
\hline
\end{tabular}

\subsubsection{Admixture}

To provide adequate workability, it was necessary to add superplasticizer in a given concrete mix. The new generation poly carboxylic ether-based superplasticizer (Auromix 400) was used. The various properties of admixture provided by the manufacturing company are under Table 2 .

Table 2. Typical properties of Auromix 400

\begin{tabular}{cc}
\hline Appearance & Light yellow coloured liquid \\
\hline $\mathrm{pH}$ & Minimum 6 \\
\hline Volumetric mass @ 200 C & $1.09 \mathrm{~kg} /$ litre \\
\hline Alkali content & $\begin{array}{c}\text { less than } 1.5 \mathrm{~g} \mathrm{Na} \mathrm{O}_{2} \mathrm{O} \text { equivalent / } \\
\text { litre of admixture }\end{array}$ \\
\hline
\end{tabular}

\subsubsection{Aggregate (Coarse and Fine Aggregate)}

Aggregates used in experimental work were obtained from river located in district Ganderbal of Kashmir. The properties of both fine and coarse aggregate evaluated as per IS: 2386 (Part 3)-1963 are given in Table 3. For coarse aggregate, particles of size varying from $10 \mathrm{~mm}$ to $4.75 \mathrm{~mm}$ were used. After performing the Sieve analysis, it was found that the sand collected was in conformity to IS: $383-1970$ 
Table 3. Properties of aggregate

\begin{tabular}{cccccc}
\hline Property & $\begin{array}{c}\text { Coarse } \\
\text { aggregate }\end{array}$ & $\begin{array}{c}\text { Fine } \\
\text { aggregate }\end{array}$ & $\begin{array}{c}\text { Indian standard } \\
\text { code }\end{array}$ & $\begin{array}{c}\text { IS Code limits } \\
\text { Coarse aggregate }\end{array}$ & $\begin{array}{c}\text { IS Code limits Fine } \\
\text { Aggregate }\end{array}$ \\
\hline $\begin{array}{c}\text { Specific gravity } \\
\text { (Pycnometer test) }\end{array}$ & 2.87 & & & & \\
$\begin{array}{c}\text { Water absorption } \\
\text { (Pycnometer test) }\end{array}$ & $0.49 \%$ & $2.33 \%$ & IS:2386 (Part 3)-1963 & $\begin{array}{c}\text { Should not be } \\
\text { greater than 0.6\% }\end{array}$ & $\begin{array}{c}\text { Should be in the range of } \\
(2.5 \%-3 \%)\end{array}$ \\
Fineness modulus & 7.1 & 2.52 & IS: 383-1970 & Fine sand (2.2-2.6) Zone II \\
Bulk density (kg/L) & 1.408 & - & IS:2386 (Part 3)-1963 & & \\
Loose bulk density(kg/L) & 1.25 & - & IS:2386 (Part 3)-1963 & & \\
\hline
\end{tabular}

\subsubsection{Water}

Water available in laboratory was used for mixing process. The properties of water computed as per the guidelines of IS: 3025 (Part 23)-1986 are given in Table 4.

Table 4. Properties of water

\begin{tabular}{|c|c|c|}
\hline Properties & Test results & Tolerable concentration \\
\hline $\mathrm{pH}$ & 6.0 & Shall not be less than 6 \\
\hline $\begin{array}{l}\text { Phenolphthalein } \\
\text { alkalinity }\end{array}$ & $3 \mathrm{mg} / 1$ & \\
\hline $\begin{array}{l}\text { Total alkalinity } \\
\left(\mathrm{mg} / \mathrm{L} \text { of } \mathrm{CaCO}_{3}\right)\end{array}$ & $16 \mathrm{mg} / \mathrm{L}$ & $\begin{array}{l}\text { Should not require more than } \\
25 \mathrm{ml} \text { of } 0.02 \text { normal } \mathrm{H}_{2} \mathrm{SO}_{4}\end{array}$ \\
\hline $\begin{array}{l}\text { Acidity }(\mathrm{mg} / \mathrm{L} \text { of } \\
\left.\mathrm{CaCO}_{3}\right)\end{array}$ & $2 \mathrm{mg} / \mathrm{L}$ & $\begin{array}{l}\text { Should not require more than } \\
5 \mathrm{ml} \text { of } 0.02 \text { normal } \mathrm{NaOH}\end{array}$ \\
\hline
\end{tabular}

\subsubsection{Plastic optical fiber}

Optical fiber is a thin cylindrical fiber that act as a wave guide and allow transmission of light between the two ends of fiber. Plastic optical fiber has core made out of polymethyl methacrylate, manufactured by a specialised company. Table 5 and Figure 2 shows the details and arrangement of POF.

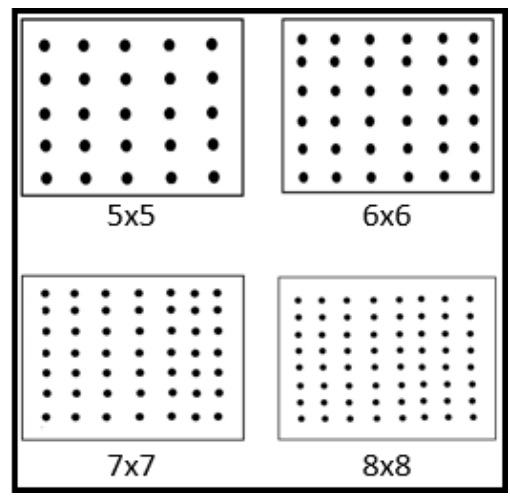

Figure 2. Arrangement of plastic optical fiber in concrete cube

Table 5. No. of POF with varying densities

\begin{tabular}{|c|c|}
\hline \multicolumn{2}{|c|}{ Plastic optical fiber with diameter $2 \mathrm{~mm}$} \\
\hline $\begin{array}{l}\text { Section } \\
\text { size }\end{array}$ & $\begin{array}{l}\text { No. of needle (fibers in surface area of } \\
150 \mathrm{~mm} \times 150 \mathrm{~mm} \text { ) }\end{array}$ \\
\hline $5 \times 5$ & 25 \\
\hline $6 \times 6$ & 36 \\
\hline $7 \times 7$ & 49 \\
\hline $8 \times 8$ & 64 \\
\hline
\end{tabular}

\subsection{Methodology}

Prior to the testing of samples, it was necessary to go through the experimental procedure started with the preparation of mould as shown in Figure 3, designing of concrete mix, casting, curing and finally preparation of specimens for testing.

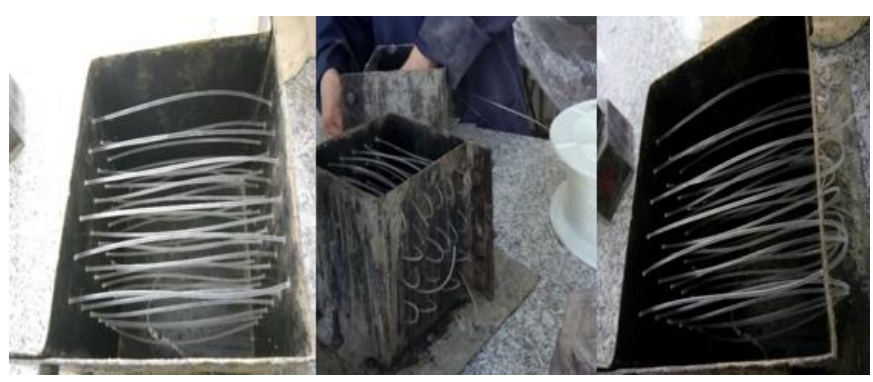

Figure 3. Mould weaved with optical fiber

\subsubsection{Preparation of mould}

In order to safeguard the alignment and arrangement of optical fiber, specific moulds were designed. The optical fiber was weaved through the holes which were drilled perpendicularly on the two opposite faces of the mould.

\subsubsection{Design mix}

After conducting various trails on almost 20 mixes, final design mix with ratio $(1: 1.5: 1.7: 0.4)$ was chosen $[15,16]$. Main purpose was to produce concrete that will flow by its own weight without the need of any vibration or tamping for compaction purposes. The quantity of ingredients used are mentioned below:

Portland Cement $-500 \mathrm{~kg} / \mathrm{m}^{3}$

Fine aggregate- $750 \mathrm{~kg} / \mathrm{m}^{3}$

Coarse aggregate- $850 \mathrm{~kg} / \mathrm{m}^{3}$

Water- $200 \mathrm{~kg} / \mathrm{m}^{3}$

Superplasticizer-2\% by weight of Cement

Water: Cement- 0.4

\subsubsection{Casting and preparation for testing}

The optical fibers were weaved through the holes of mould. Mould oil was applied from inner surface of mould shown in Figure 4 and Self-Compacting Concrete was poured carefully to produce light transmitting concrete specimens. For each fiber percentage, six cubes were casted. De-moulding was done after 24 hours of casting. On the day of testing, specimens were taken from curing tank and were dried before loading them in UTM of 100-ton capacity.

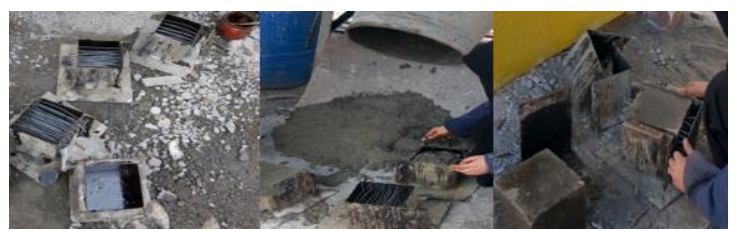

Figure 4. Main steps involved in making typical light transmitting concrete 


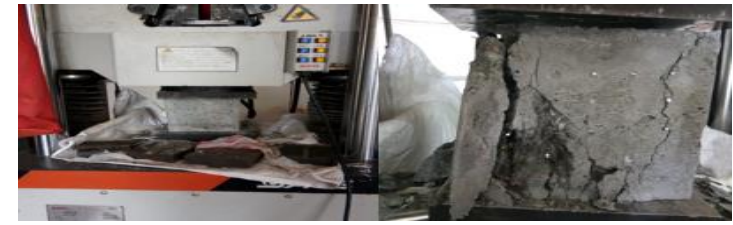

Figure 5. Test set-up and damaged form of light transmitting concrete cube

\subsubsection{Compressive strength}

The compressive strength test was carried out by following the guidelines of IS: 516-1959. The size of cube specimen was kept as that of standard $(150 \mathrm{~mm} \times 150 \mathrm{~mm} \times 150 \mathrm{~mm})$. The load was applied at the rate of $5.2 \mathrm{kN} / \mathrm{s}$. For each fiber percentage three cubes were tested at each testing age (14 and 28 days). The compressive strength was taken as average strength of three cubes. The Figure 5 shows the specimens during compressive strength test.

\subsubsection{Light transmission test}

For the measurement of light transmission intensity through the concrete cube, the apparatus know as Lux meter was used. Arrangement of apparatus is shown in Figure 6. Further to avoid unnecessary entry of light a hollow box was used. On one side of which concrete cube with optical fiber was placed and on other side Lux metre was placed. Lux meter measures the brightness of light. It consists of photocell sensor which capture and measures the light.

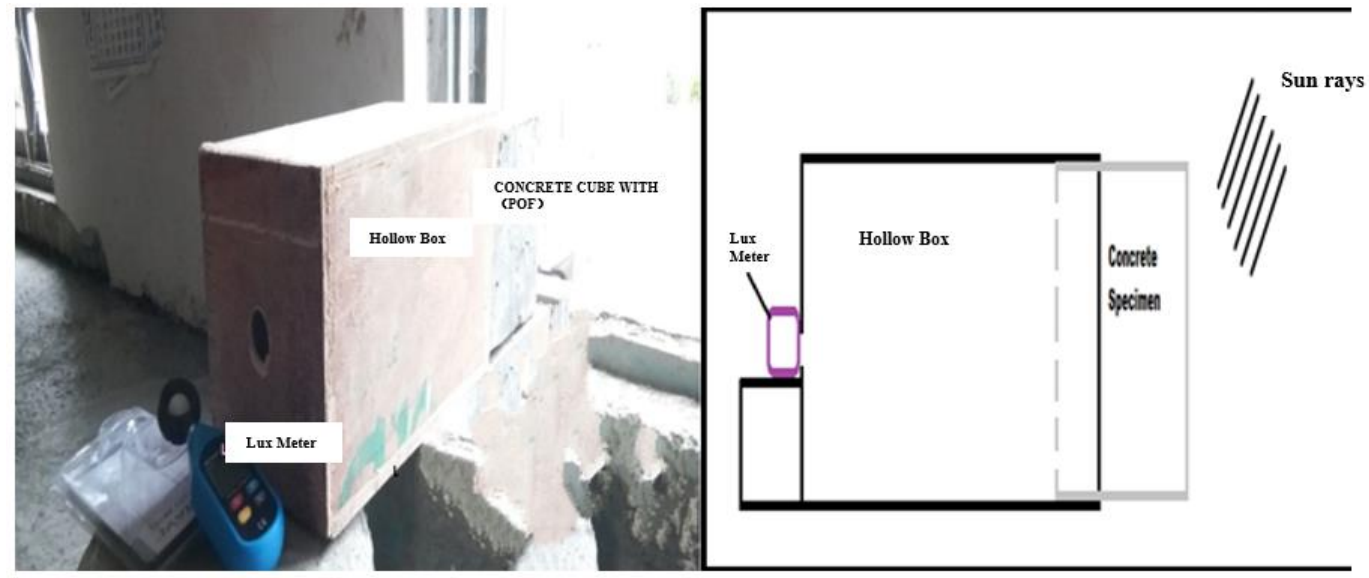

Figure 6. Experimental set-up for the measurement of Lux valves

\subsubsection{Rebound hammer test}

Rebound hammer test is a non-destructive test which provides a rapid and convenient indication of compressive strength both in situ as well as in laboratory. The rebound hammer test was performed as per IS: 13311 (Part 2)-1992. It works on the principle that extent of rebound given by spring controlled mass depends upon the surface hardness of the concrete. The rebound number or rebound index is computed from the graduation scale provided on the rebound hammer. From each observation point six readings were taken and average of those readings were taken as rebound number for that observation point.

\section{RESULTS AND DISCUSSIONS}

\subsection{Light transmission test results}

Using sunlight as a source of illumination, the intensity of light passing through the Light Transmitting Concrete was measured as shown in Figure 6. From the Figure 7 it could be concluded that with an increase in the optical fiber density, the transmission of light through light transmitting concrete also increases. Maximum illumination intensity was obtained in a cube with optical fiber density $8 \times 8$ which was 84 lux at box face after that the maximum illumination was found in $7 \times 7$ optical fiber density which was 69 lux, for $6 \times 6$ density 31 lux and finally for $5 \times 5$ it was observed 18 lux. The light transmission intensity increased about $78.5 \%$ from $5 \times 5$ to $8 \times 8$ fiber density concrete cube. Thus, the results show that transmission of light through concrete material is proportional to the amount of optical fiber present in the concrete cube, such that intensity of light transmission increase with the increase of optical fiber density.

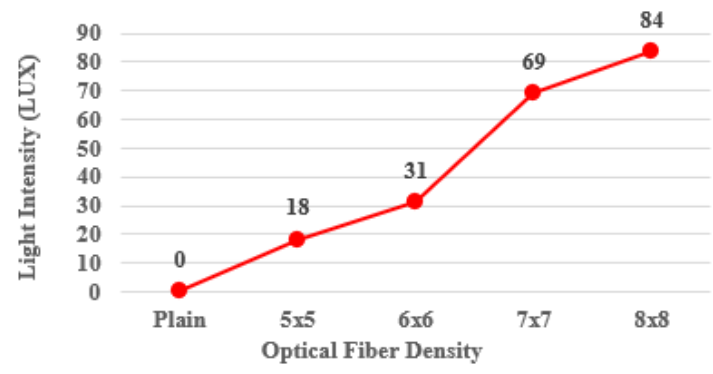

Figure 7. Amount of light passing through the light transmitting concrete

\subsection{Compressive strength results}

From the compression resistance test, the affect of adding Plastic Optical Fiber on Concrete Compressive Strength at different ages was studied as shown in Figure 8. The plotted results showed that the maximum strength possessed by $7 \times 7$ density specimen which was about $15.057 \%$ more than the reference concrete cube at 28 days of age. For $6 \times 6$ density specimen, compressive strength was about $9.952 \%$ more than conventional concrete cube at the age of 28 days. For $5 \times 5$ density specimen, compressive strength was about $4.8 \%$ more than normal concrete cube at the age of 28 days. From the above results it seems that with the increase in fiber density, the compressive strength also increases. This increasing trend of compressive strength with increasing fiber density was not shown by $8 \times 8$ fiber specimen. In fact, there was a reduction of 
compressive strength for $8 \times 8$ fiber density specimen and was only $2 \%$ greater than the conventional concrete specimen. Figure 9 shows the comparison of Compressive Strength between Normal and Concrete Cube with different Fiber Density. Decrease in strength after a certain rise in fiber content might be due to the reason that with the increase in fiber content more and more voids get introduced thus breaking the continuity of matrix and making the concrete less denser. This concludes that presence of plastic optical fiber in a concrete material has a significant impact on compressive strength and gives a favourable result for improving the compressive strength of concrete as long as the percentage of fiber does not exceed the optimum limits.

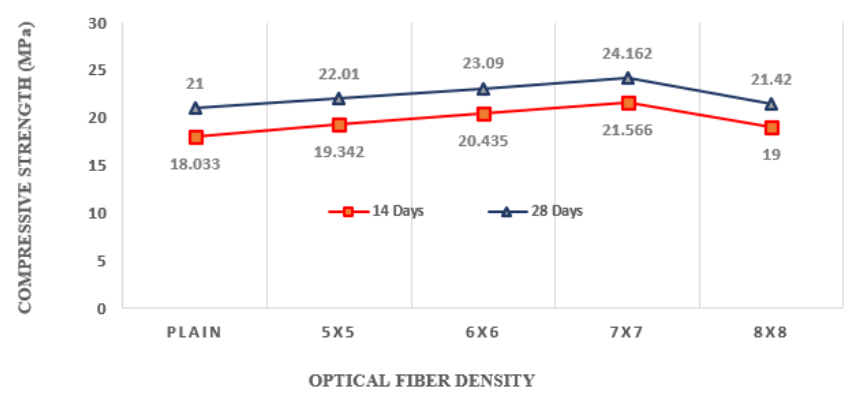

Figure 8. Effect of plastic optical fiber on concrete compressive strength at different ages

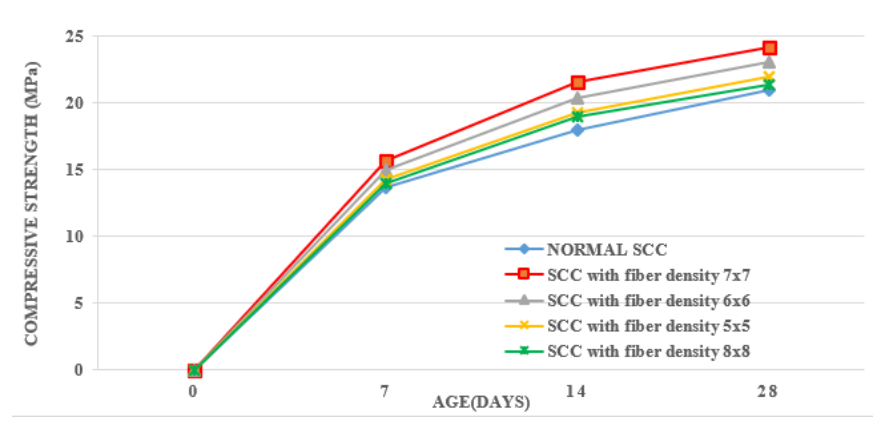

Figure 9. Comparison of compressive strength between normal and concrete cube with different fiber density

\subsection{Stress - Strain behaviour for light transmitting concrete}

From the stress-strain curve, the main parameters that define the behaviour of concrete under compression could be studied. With the inclusion of optical fiber the behaviour of concrete material changes from fragile to ductile one. Thus, by arresting cracking mechanism, the concrete specimen that contains plastic optical fiber has ability to show higher strain as compared with regular concrete as shown in Figure 10. Since these fibers act as reinforcement they improve energy absorption capacity thus enhancing toughness (which is given by the area under stress- strain curve) and strain at peak stress. There is a decrease in compressive strength with further addition of fiber by about $11.3 \%$ from $7 \times 7$ to $8 \times 8$ (with respect to $7 \times 7$ ). This might be due to the fact that with increase in fiber density in concrete material the spacing between the fiber decreases thus causing discontinuity in concrete matrix. Also, the weak interfacial transition zone between the matrix and fiber surface, leads to the development of high stress concentration causing the failure of a material at much lower value.

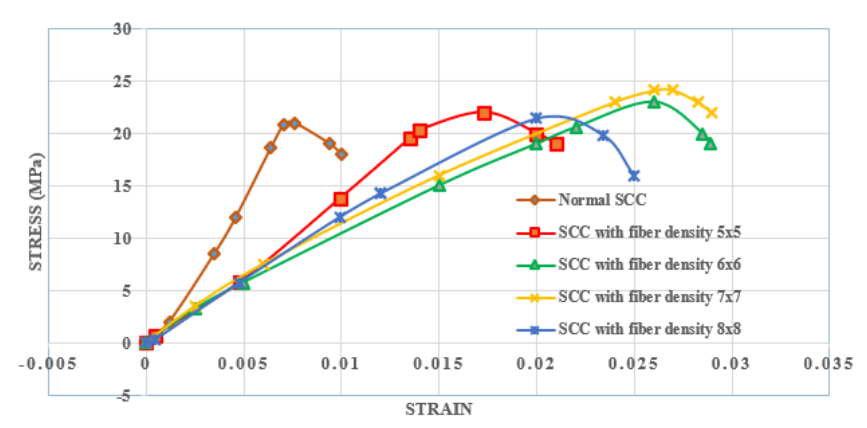

Figure 10. Stress-strain curve

\subsection{Effect of plastic optical fiber on the rebound number}

For rebound hammer test, the points where the fiber existed in specimen were made visible so that the testing was done in two stages:

* By avoiding the impact of fiber.

* By undertaking the effect of fiber.

It was found that the rebound number increased over fiber by around $5 \%$ as shown by Figure 11 . From this it could be concluded that the surface hardness obtained over fiber is greater than in the region nearby fiber.

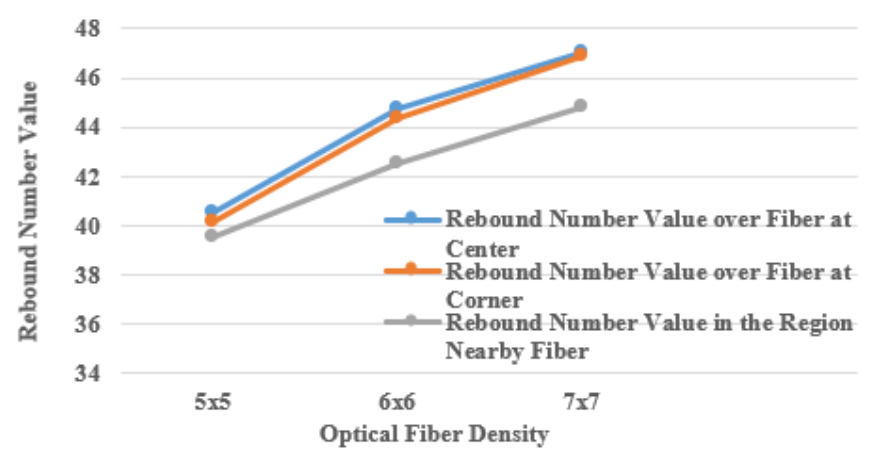

Figure 11. Effect of plastic optical fiber on the rebound number

\section{CONCLUSIONS}

With reference to the previous discussion regarding the capability of light transmission, compressive strength, and manufacturing of light transmitting concrete the following conclusions can be made.

1) Light transmitting concrete can be produced by adding Plastic Optical Fiber (Light Transmitting Element) in a concrete mix. By designing special type of moulds it helped in placing the optical fibers firmly in proper alignment.

2) The amount of light transmitted through concrete material depends upon the density of the optical fiber used such that with an increase in fiber density, the transmission of light also increased. Thus, maximum light transmission intensity of 84 lux was obtained for the concrete specimen of fiber density $8 \times 8$.

3) The result of the compression resistance depends on the percentage of the plastic optical fiber used. The optimum density for $2 \mathrm{~mm}$ diameter fiber to be used in light transmitting concrete specimens was found between $7 \times 7$ 
and $6 \times 6$ (49 \& 36 number of fiber strands in a surface area of $22500 \mathrm{~mm}^{2}$ ). The strength given by $7 \times 7$ fiber density specimen was about $15.075 \%$ greater than reference concrete specimen. Beyond this fiber density there was decrease in strength because of the excess fiber content which might have increased the voids or empty spaces within the concrete specimen.

4) The addition of optical fiber increased the toughness and strain at peak stress. Thus, increasing the ability of concrete material to absorb more energy prior to failure.

5) Rebound number computed over fiber increased by about $5 \%$ than in the region nearby fiber which indicates that the loss of impact energy over fiber is less than in the region around fiber. From this it can concluded that at the location of fiber impact resistance improves.

From the above conclusions it is clear that the plastic optical fiber does not have a negative impact on compressive strength of concrete. It retains all the properties of good concrete as long as percentage of fiber does not exceed certain optimal limit. Because of its capacity to bear the load, light transmitting concrete can be used in various field of architecture and design. By allowing the penetration of sunlight, this new building material connect us with the nature by maintaining a contact with outside living environment and helps us to draw the huge benefits associated with sunlight. So Light transmitting concrete can be considered as a green energy saving construction material and can have a good scope in a highly populated country like India.

\section{REFERENCES}

[1] Nagaraju, K. (2017). An overview of energy sector in India. International Journal of Science and Research, 6(3): 1589-1594.

[2] UNEP. (2018). Sustainable Buildings and Construction for India: Policies, Practices and Performance. Influence of Indian Buildings on climate change (UNEP SBCISustainable Buildings \& Construction Initiative).

[3] CMIE. (2001). Economic Intelligence Service Report 2001, Centre for monitoring Indian Economy, Mumbai, India.

[4] Energy Policy of India. http://en.wikipedia.org/wiki/Energy_policy_of_India, accessed on Jan. 152020.
[5] Kamdi, A.B. (2013). Transparent concrete as a green material for building. International Journal of Struct. \& Civil Eng., 2(3): 172-175.

[6] Sasidharan, J., Naga Sai Teja, A., Sakthivel, K., Manickavel, D. (2017). Translucent concrete. International Journal of Engineering Research \& Technology, 6(4). http://dx.doi.org/10.17577/IJERTV6IS040596

[7] Sawant, A.B., Jugdar, R.V., Sawant, S.G. (2014). Light transmitting concrete using optical fiber. Int. J. of Inventive Engg. and Sciences, 3(1): 23-28.

[8] Al-Kurdi, N., Abdel-Aziz, D., Alshboul, A. (2015). The impact of using light transmitting concrete on energy saving in office buildings-case of Jordan. Research Journal of Applied Sciences, Engineering and Technology, 11(6): 578-586. https://doi.org/10.19026/rjaset.11.2016

[9] Bashbash, B.F., Hajrus, R.M., Wafi, D.F., Alqedra, M.A. (2013). Basics of light transmitting concrete. Global Advanced Research Journal of Engineering, Technology and Innovation, 2(3): 76-83. https://doi.org/10.13140/RG.2.2.30481.33121

[10] Altolomate, A., Alatshan, F., Mashiri, F., Jadan, M. (2016). Experimental study of light-transmitting concrete. Int. J. of Sustainable Building Tech. and Urban Development, 7(3-4): 133-139. https://doi.org/10.1080/2093761X.2016.1237396

[11] Salih, S.A., Joni, H.H., Mohamed, S.A. (2018). Evaluation of the mechanical properties of translucent concrete. International Journal of Engineering Trends and Technology, 58(3): 158-164. https://doi.org/10.14445/22315381/IJETT-V58P230

[12] Salih, S.A., Joni, H.H., Mohamed, S.A. (2014). Effect of plastic optical fiber on some properties of translucent concrete. Eng. \& Tech. Journal, 32(12): 2846-2861.

[13] Fowler, D.W. (1999). Polymers in concrete- a vision for the $21^{\text {st }}$ century. Cement \& Concrete Composites, 21(5$6)$ 449-452. https://doi.org/10.1016/S09589465(99)00032-3

[14] https://hemantmore.org.in/science/physics/optical-fibreprinciple-andworking/8448/, accessed on 15 Jan 2020.

[15] IS 10262:2009 comparison with IS 10262:1982 recommended guidelines for Concrete Mix Design.

[16] Poulson, B. (2002). Specification and Guidelines for Self-Compacting Concrete. (C) EFNARC 2002. 